\title{
Hydro-Geophysical Study for Well Design in Lower Reaches of Kasai River Basin, Eastern India
}

\author{
Ranjan Sinha ( $\square$ rsinha1368@gmail.com ) \\ Vedanta Ltd \\ Shalivahan Shrivastava \\ IIT (ISM): Indian Institute of Technology
}

\section{Research Article}

Keywords:

Posted Date: January 14th, 2022

DOI: https://doi.org/10.21203/rs.3.rs-1223067/v1

License: @ (i) This work is licensed under a Creative Commons Attribution 4.0 International License. Read Full License 


\section{Abstract}

Saltwater intrusion and up coning in coastal aquifer is a common phenomenon brought either due to flow of seawater into freshwater aquifer originally caused by groundwater abstraction near the coast or due to wrong casing design of water wells. This necessitates a study of aquifer disposition along with demarcation of fresh water saline water interface of Kasai River basin, Eastern India to determine the depth to freshwater and recommend the borehole design. In this study geophysical and hydrogeological techniques were employed to map to demarcate fresh and saline water interface. The phenomenon of saline water up coning is also noticed and accordingly water wells have been designed. For the said study, twenty two geophysical logs, sixty five lithological logs and hydrogeological data of eighty eight sites spread across Kasai River basin were utilized. The study shows that there are three regional aquifers exist in the area. It is recommended that water wells in the study area is to be constructed with artificial gravel packing of size 2-3mm and screen slot size is suggested to be $1.2 \mathrm{~mm}$. Since the sites are affected with saline water, hence isolation of zone is mandatory with proper cementing material or packer. This research work is able to develop a design model for the boreholes located in the area. The work as a whole will serve as a vital role in scientific management of groundwater resource and enable the rational planning in coastal aquifers so as to avoid fresh and saline water intermixing and up-coning.

\section{Highlight Of The Paper}

- Key marker clay horizons demarcated using resistivity peaks and gamma counts

- Hydrostratigraphic framework using well correlation established 3 aquifer groups

- Hydrostratigraphic model with fresh-saline water interface has been constructed to visualize the aquifer disposition along with salinity and aquifer wise fresh-saline water interface has been established in the study area

- Well-designed based on grain size analysis of aquifer zones demarcated.

- Detailed mapping will help policy makers to minimize risk in water resource planning

\section{Introduction}

Saline water intrusion into the coastal aquifer has been recognized as major concern and challenge around the world (Barwani and Helmi 2006; Adeoti et al. 2010). The intrusion occurs as a result of the induced flow of seawater into freshwater aquifers. The induced gradients usually cause migration of saltwater from the sea towards a borehole where groundwater is being pumped from aquifers that are in hydraulic connection with the sea (Abdalla et al. 2010). This is driven by a violation of delicate hydrogeological balance that exists between freshwater and seawater in coastal aquifers due to large scale groundwater abstraction occasioned by rapid urbanization around the coast area adjoining Kasai River (Goswami 1968; Dhar 2011; Das 2014; Maity et al.2017). Intrusion of saltwater of the smallest percentage into freshwater is enough to reduce its potability (Custodio 1987). It is becoming more difficult worldwide for groundwater developers to construct boreholes in areas adjoining the sea or lagoon without encountering saline water (Oladepo et al. 2014).

Due to the proximity of some regions to the Bay of Bengal and due to the tidal effect, the general population is faced with problems of freshwater from the subsurface and as such it becomes difficult for groundwater user to construct boreholes in the area in the Kasai Basin. Due to unscientific method of water well construction, saline water up coning is a common phenomenon which affects the cropping pattern and the potability of water also becomes bad which alarms the livelihood of the concerned area (Sheriff and Singh 1999; Dhar 2011; Das 2014). The salinity of the aquifer also increases due to wrong placement of production screen of water well against the desired water bearing zone and due to wrong use of packing material in the well annulus. In many cases the zones tapped are not isolated from saline zone based on the quality of groundwater. Clogging of well is also common phenomenon due to wrong selection of slot size of screen as a result of which the yield of wells as well as quality of water deteriorates.

The water well is the heart of water supply system for irrigation and drinking water needs. Without any reliable, efficient and economical supply of water, the entire water supply system becomes nearly useless. The well must be capable of producing adequate water during peak seasonal use and under draught conditions. Hence, the water wells must be properly designed to ensure long life, efficiency and economic operation. Keeping these vital factors in mind hydro geophysical study has been conducted to design optimum water well in the study area.

With this thought in the backdrop, it is felt mandatory to understand the aquifer geometry in terms of top, bottom and thickness of the aquifers of the area along with its salinity variation and design proper well for individual aquifers based on grain size analysis of various granular zones. Therefore, proper hydro-geophysical study is a pre-requisite for the design of water wells. The previous works by many researchers reviewed, infers that due to proximity of the area to the Bay of Bengal, the general population is faced with problems of tapping freshwater zones and identifying its interface with saline water. It is becoming more difficult for groundwater user to construct water wells in 
that area. Saline water up-coning or intermixing of groundwater of different salinity from separate aquifer due to improper placement of screen and due to improper sealing arrangement by cement or inflatable packer has reduced the potability of water in the area, which necessitates the use of borehole geophysical logging data to delineate fresh and saline water zones. The use of geophysical logs (electrical and gamma) aided by detailed lithological logs provide sequence of formations and its areal extent when correlated between wells (Keys 1988; Chaturvedi et al. 2003; Sinha et al. 2009; Sinha and Kumar 2019) and can identify aquifer tops and bottom (Reese and Wacker 2007). The applicability of geophysical borehole logging in differentiating freshwater- saline water zone is brought about by its ability in lithological differentiation (Doll 1948). The precise identification of aquifer tops and bottom will help placing the casing and screen against desired aquifer zone as well as place the cementing material to separate fresh and saline zone within a borehole.

Therefore, this study is aimed at reducing the challenges encountered in groundwater exploration and exploitation in this part of Kasai basin through use of existing borehole logs in predicting and separating the freshwater and saline water zones both vertically and laterally by estimating depth to drill, lithologic unit variation, placement of screens during well assembly lowering and recommending buffer zones at minimal cost for groundwater management, especially in area where geophysical, lithological, grain size analysis and electrical conductivity data of groundwater is available.

A relatively precise estimate of depth to aquifer is achieved through existing twenty two numbers of geophysical logs, sixty five numbers of lithological logs, eighty eight numbers of monitoring wells with EC measurements used to map the salinity variation in the study area. The grain size analysis of four lithological samples was used to decide screen slot size.

\section{Site Description, Geological And Hydrogeological Setting}

The study area (Fig. 1) lies in the eastern part of India is bounded between latitude $21.799^{0} \mathrm{~N}$ to $22.624^{0} \mathrm{~N}$ and longitude $87.229^{0} \mathrm{E}$ to $88.147^{0}$ E covering an area of $\sim 4673 \mathrm{~km}^{2}$. The area encompasses alluvial plain of the lower reaches of Kasai River basin. The study area is in parts of Purba and Pashchim Medinipur district of Westbengal, India. The Bay of Bengal is situated towards its south. The general slope of the landscape is towards the southeast, where the land gradually approaches the coast line. The Kasai River forms the principal drainage system in the study area which is the main perennial river. The overall drainage pattern is of a composite nature such as dendritic, sub-dendritic, trellis, radial and sub-rectilinear. The major tributaries of Kasai River are Kumari, Bhairabanki and Kalighai and tributaries of Silai River. Small area in the outfall region is drained independently by Rasulpur River.

Various studies have been conducted by Central Ground Water Board (CGWB) in various phases in this area. The sedimentary formation in the northern part of the area is overlain by laterite in isolated patches (CGWB 2013). The area is underlain by the unconsolidated quaternary and tertiary formation in the alluvial and coastal plains (Fig. 1). Numerous workers have studied the geology and hydrogeology of the study area. Besides shallow aquifers, deep confined aquifers at various depths exist in the study area (Machiwal et al. 2016; Biswal et al. 2018). The MioPliocene deposit is persistent throughout the area with the presence of marker bed (grey clay) which separates the upper lithological system (ULS) and lower lithological system (LLS) identified in this area (CGWB 2013). The ULS comprises of unconfined to semi confined aquifers comprising newer alluvium. The newer is predominantly argillaceous and grey in colour. The water level of unconfined aquifer tapped by shallow dug wells range between $3 \mathrm{~m}$ below ground level $(\mathrm{m} \mathrm{bgl})$ during post monsoon period to $5 \mathrm{~m}$ bgl in pre-monsoon period. The water level of shallow tube wells tapping zones between $50 \mathrm{~m}$ bgl to $150 \mathrm{~m}$ bgl ranges between 6-18 m bgl (CGWB 2019). The water level, yield of wells and draw down (DD) observed through open dug wells (DW), shallow tube wells (STW) and deep tube wells (DTW) are shown in Table-1 (CGWB 2013, 2019). The LLS comprises of older alluvium that exhibits characteristics sheds of yellow to reddish brown. The LLS comprises semi-consolidated sediments of upper tertiary period. The LLS is mainly of confined aquifers. The water level of the area measured through wells tapping different aquifer zone ranges between $4-14 \mathrm{~m}$ bgl. The excessive abstraction of groundwater from coastal aquifer may trigger ingress of sea water (Singh 2013; Maity et al. 2017). Despite the average rainfall of the area being medium to high ( 1234-4136 mm), the area experiences acute scarcity of groundwater, especially during summer as the area is an agrarian, have created conflicts between various resource users and interest groups, between ecologists, environmentalists, engineers, geoscientists and groundwater users in the coastal area (Mandal et al. 2013). The alluvial plains and coastal tracts in the area constitute fertile agricultural land, but lack of assured water supply for irrigation has impeded the agro-economic growth of the area (Sinharay 2014). The Haldia township, a center for many petrochemical businesses and being developed as a major trade port is bordered by Haldi River an offshoot of the Ganges River. The effect of salinity in ground water has increased over the years, and efforts to check this will possibly be one of the biggest challenges (Dhar 2011).

Unfortunately, none of the work did make an attempt on to solve the issue by designing proper well based on aquifer geometry and its salinity.

\section{Methodology}

Geophysical logging is the best tool that reduces the challenges for delineation of fresh and saline water zones and finalization of well design (Akinlalu et al. 2018). Geophysical logs of twenty two sites were considered along with sixty five numbers of lithological logs. The drill cutting 
samples were used for gross lithological descriptions, identification of major mineral assemblages. Sample description is utmost important for demarcation of key horizons for correlation with other wells and also forms the base for formation and fluid property evaluation. These descriptions provided very valuable clues for the electro log and gamma log interpretation and lateral correlation of key marker events. Since a number of wells are available in the area, well to well correlation has been attempted to find regional marker horizons using lithological clay markers with diagnostic geophysical characteristics for aquifer mapping. The aquifer mapping exercise aided to determine the top, bottom and thickness of the aquifers. The aquifer zones inferred through correlation of geophysical and lithological logs helped in determining the best water production zones to be tapped to design water wells for various purposes.

Electrical conductivity (EC) values of eighty eight monitoring wells were used to map the salinity variation of the aquifers of the study area. The EC values were also considered to calibrate the water quality of granular zones identified through self-potential (SP) and other electrical logs. One of the main objectives of study of variation of EC of the area is to assess the suitability of groundwater for drinking and irrigation purposes. Bureau of Indian Standard (BIS 2012) has recommended drinking water standard for total dissolve solids a limit of $500 \mathrm{mg} / \mathrm{l}$ (corresponding to about EC of $750 \mu \mathrm{S} / \mathrm{cm}$ at $25^{\circ} \mathrm{C}$ ). Beyond this value, the groundwater is considered as saline. However, in places where there is no other source, this value is extended to $2000 \mathrm{mg} / \mathrm{l}$ (corresponding to $3000 \mu \mathrm{S} / \mathrm{cm}$ at $25^{\circ} \mathrm{C}$ ). On the basis of classification, the natural groundwater of India has been categorized as desirable, permissible and unfit for human consumption for shallow aquifers of India (CGWB 2010; CGWB 2014). Depending on the dissolved salts, the quality of groundwater in the area has been depicted with the help of isoconductance maps. In order to assess the salinity variation of groundwater of aquifers of the area, the analyzed groundwater samples for EC of groundwater samples collected during May, 2019 through monitoring system of CGWB ( CGWB 2019) and other exploratory wells have been considered to show distribution patterns of salinity in different ranges of suitability for drinking purposes. The grain size analysis of four sites have been used for most important consideration in designing the well screen and to ensure that the drawdown within the well is minimized with an optimum entrance velocity in order to minimize head losses across the screen (Driscoll 1986) and thus increasing the well efficiency. Using the lithological cuttings and sieve analysis data, uniformity co-efficient were calculated for various zones at locations to decide the gravel pack material (Roscoe 1990).

\section{Aquifer Mapping And Saline-fresh Interface Demarcation}

The relatively homogeneous nature of the study area necessitates the need to employ geophysical logging tools such as natural gamma log combined with resistivity log to infer the lithology and to locate saltwater-freshwater interface geometry. The study is aimed to reduce the challenges encountered in groundwater exploration in coastal regions. Through the use of existing borehole logs in predicting the average saltwater-freshwater interface, estimation depth to drill, lithological unit variation, placement of screen during borehole construction and recommending buffer zones, so that little cost will be expended in the exploitation of groundwater, especially in areas where the log data are available. The results of the subsurface study using geophysical logs and drill cutting description are presented as geo-electric sections and maps. The geo-electric sections enabled the identification of various lithological units within the study area. The maps were utilized to determine the variation of depth of fresh water and saline water as defined by BIS 2012 across the study area. The geophysical borehole logging data correlated with lithological logs and calibrated with the EC of the water samples collected from various depth through various monitoring wells and exploratory wells and were presented in the form of fence diagram. The three dimensional fence diagram thus erected shows the demarcation of freshwater and saline water zones.

\subsection{Aquifer Disposition by Correlations of Geophysical and Lithological Data}

Saltwater intrusion into aquifer units of freshwater has decreased the potability of water in coastal region which necessitates the use of geophysical logging data to delineate saline zones and locate freshwater aquifers (Figg and Rodriguess 1981; Keys 1988). The applicability of geophysical borehole logging in saltwater intrusion studies is brought by its ability in lithological differentiation. For the regional subsurface correlation, initially each log was considered separately and groups having diagnostic characteristics were identified. Each group generally comprised of a number of individual beds. The comparative characteristics of these groups in relation to those overlying and underlying horizons were also noted. Further, with the help of the observed characteristics, the markers having distinctive geophysical characteristics, sharp contrast against the neighboring strata and spatial extension throughout the area were identified along selected sections and extended from one well location to the other. The available SP, resistivity and natural gamma logs measured in terms of cycles per second (CPS) in the area have been analyzed qualitatively. The use of various geophysical logs ( SP, resistivity and natural gamma logs ) for aquifer demarcation and quality interpretation were explained by Archie 1942; Chaturvedi et al. 2003; Doll 1948; Keys 1988; Sinha et al. 2009; Kumar and Sinha 2010; Sinha and Kumar 2019; Reese and Wacker 2007. The quality of formation water was estimated though SP and resistivity values of the mud fluid.

Efforts have been made to establish aquifer disposition and define aquifer geometry by integrating the sub-surface lithological and geophysical datasets of wells located in the study area (Fig. 1). Further constrains and details in the framework have been brought by infilling

Page $4 / 24$ 
from the partial datasets obtained in other wells. The lithology pertaining to marker clay horizons was studied in detail in terms of granularity, tone, texture and mineral content. This lead to identification of three regional aquifers with two types of markers, the regionally co-relatable markers and some very localized events. The regional clay layers have been correlated throughout the study area and extended to other locations where there are no geophysical logs to define the aquifer groups but the lithological description clearly indicates similarity with the high confidence and log calibrated areas. The aquifer disposition along with marker clay horizon is shown in Fig. 2 and 3.

\subsection{Geo-electric Section Using Borehole Data}

Two geoelectric sections one each on the either side of the Kasai River (Fig. 2a and 2b) and a three-dimensional fence diagram (Fig. 3) has been generated across the study area.

\subsubsection{Geo-electric Section on the Eastern Bank of Kasai River}

Figure 2a shows the correlation section of boreholes at Daspur, Keshabpur, Gopalpur, Lakhya and Haldia oriented approximately in NW-SE direction along the Eastern bank in the study area. A quick look into the section shows that there exits three regional aquifer zones separated by two regional clays. ULS and LLS are separated by a grey clay horizon which exists throughout. The ULS consists of two aquifer groups separated by a regional clay horizon. The aquifer groups consist of granular material with occasional clayey material. The granular zones within Aquifer-I consists of sand (resistivity ranging between $30-45 \Omega \mathrm{m}$ ). However, the top aquifer is more clayey in nature having resistivity in the range of 15-18 $\Omega \mathrm{m}$ and gamma count in the range of 70-115 CPS towards the southern part of the section and as such no shallow groundwater structure exists in this group towards south (Sinharay 2014; CGWB 2013). There are few localized sand available in and around Lakhya. In and around industrial town of Haldia, the top part is not suitable for groundwater development because of clayey nature. The Aquifer-II within ULS is mostly sandy and many shallow water wells tapping this zone are inventoried. The resistivity ranges between $15-20$ $\Omega \mathrm{m}$ and gamma in the range of 50-60 CPS, inferring presence of saline water bearing sand. Aquifer-I and Aquifer-II is separated by a marker clay (MC) horizon. The gamma count of the MC ranges between 12-85 CPS. The Aquifer -III is the major aquifer system exists below grey clay horizon with thick granular zones with localized intercalations of clay within this group. The granular sand present within this aquifer is mostly connected. The granular nature of Aquifer-III is predominantly sand; the resistivity ranges between $40-50 \Omega \mathrm{m}$ and gamma in the range of 35-45 CPS, inferring the presence of freshwater bearing sand. The depth of its occurrences and the relevant characteristics picked up by insitu electrical and gamma counts of a few of the selected wells in different geological domains are presented in Table 2.

\subsubsection{Geo-electric Section on the Western Bank of Kasai River}

Figure $2 \mathrm{~b}$ shows the correlation section of boreholes at Debra, Jalchak, Bhagawanpur and Maheshpur oriented approximately in NW-SE direction along the western bank of Kasai River in the study area. A perusal of the section shows that, in this part also, three regional aquifer zones exists separated by two regional clays. In the western bank of the Kasai River also ULS and LLS is separated by a grey clay horizon which exists throughout the area. The ULS consists of two aquifer groups separated by regional marker clay (MC) horizon. The gamma count of regionally extensive clay horizon within ULS ranges between 12-85 CPS and exists throughout the area indicating two prominent aquifer groups (Aquifer-I and Aquifer-II).The aquifer groups consist of granular material with occasional clayey material. The northern part of Aquifer-I is more clayey in nature compared to the southern part of the area and as such no shallow groundwater structure exists in this group towards south. The resistivity of aquifer zone is in the range of $45-48 \Omega \mathrm{m}$ and 35-38 CPS from Debra to Bhagwanpur. However, the lithology becomes clayey (10-12 $\Omega \mathrm{m}$ and 90-110 cps) towards Mahespur. The electric and gamma properties of the formation interpreted infer that one clay horizon of resistivity ranges between 18-20 $\Omega \mathrm{m}$ and gamma count ranges between 125-135 CPS exists within Aquifer-I that pinches out near Jalchak and broaden towards Mahespur. This formation becomes sandy in nature towards Debra (20-25 $\Omega \mathrm{m}$ and $90-95 \mathrm{cps})$. The Aquifer-II within ULS is mostly sandy in nature and many shallow water wells tapping this zone are inventoried. The Aquifer -III is the major aquifer system inferred with thick granular zones with localized intercalations of clay within this group. The granular sand present within this aquifer is mostly connected. The thickness of alluvium increases southwards. The granular zone between MC and grey clay horizon consists of sand of various grades; sand mixed with clay and clay layers. The resistivity of aquifer ranges between $70 \Omega \mathrm{m}$ in the northern part to $10 \Omega \mathrm{m}$ in the southern part. The gamma count of this granular zone is however is very low, indicating the presence of sand all through even though the resistivity is low which may be due to saline nature of the aquifer. The resistivity of mixed zone ranges between $25-8 \Omega \mathrm{m}$ and gamma count ranges between 90-100 CPS. The intervening clay layer records resistivity of the value ranging between $15-18 \Omega \mathrm{m}$ and gamma as $140-145$ CPS. Below Aquifer-II, exists a regionally extensive sticky, grey in color clay all through the section. The geophysical signature of grey clay is same all through. The gamma count of the grey clay ranges between 140-180 CPS. The grey clay horizon between Bhagwanpur and Mahespur deepens towards Mahespur. The granular zone overlying the grey clay is more prominent than the one underlying it along the section.Within LLS, the clay horizons are not extensive, and sand at various levels is interconnected, forming a single aquifer system. The resistivity of sand layers of Aquifer - III ranges between 35-42 $\Omega \mathrm{m}$ and gamma count as 50-55 CPS indicating fresh water bearing sand.

(b) Along Western bank of Kasai River (Debra and Mahespur section)

Page 5/24 


\subsubsection{Three Dimensional Fence Diagram Showing Lithological Disposition with Salinity Variation in the Basin}

A broad aquifer disposition framework has been erected using the geophysical logs of 22 wells to define major lithological units and lateral correlativity of key marker horizons. Diagnostic clay horizons were picked in these wells and correlated regionally. Further constrains and details in the framework have been brought by infilling from the partial datasets obtained in other 65 wells. The lithology pertaining to marker clay horizons were studied in detail in terms of granularity, tone, texture and mineral content. This lead to identification of two types of markers - the regionally co-relatable markers and some very localized events. The regional clay layers have been correlated throughout the study area and extended to other locations where there are no geophysical logs to define the aquifer groups but the lithological description clearly indicates similarity with the high confidence and log calibrated areas. The quality of formation water was estimated though SP and resistivity values of the mud fluid.

The quality of formation water in terms of salinity was estimated though SP and resistivity values of the mud fluid. The conventional formula for estimation of formation water quality $\left(R_{w}\right)$ is given below:

$S P=-K \log \left(R_{m} / R_{w}\right)$

Where, $\mathrm{K}=60+0.133 \mathrm{~T}$; $\mathrm{T}$ is borehole temperature in ${ }^{0} \mathrm{~F}$ or

$\mathrm{K}=65+0.24 \mathrm{~T}+; \mathrm{T}$ is borehole temperature in ${ }^{0} \mathrm{C}$

$\mathrm{R}_{\mathrm{m}}$ : Resistivity of mud and $\mathrm{R}_{\mathrm{w}}$ : Resistivity of formation water

Examination of this equation enables to understand the applicability and effectiveness of the SP log.When resistivity of mud ( $\left.R_{m}\right)$ is greater than resistivity of formation water $\left(R_{w}\right)$, the SP is negative, indicating that the formation water is less resistive than the borehole mud, and greater the contrast the higher will be the amplitude of SP curve. When $R_{m}$ equals $R_{w}$, the SP is zero implying that when there is no contrast in the chemical quality infers that the resistivity of formation water is equal to resistivity of mud. When $R_{m}$ is less than $R_{w}$, the SP is positive indicating that the chemical quality of formation water is better than of the borehole mud in turn meaning that the aquifer is relatively fresh water bearing and higher the amplitude means a clean / highly permeable aquifer. The $\mathrm{R}_{\mathrm{w}}$ calculated is standardized with known salinity value (EC) of the zones encountered of the nearby water well. The maximum EC value of water is considered as $750 \mu \mathrm{S} / \mathrm{cm}$ for freshwater ( BIS, 2012). The SP value corresponding to $750 \mu \mathrm{S} / \mathrm{cm}$ is considered as fresh water and any departure from this point in SP curve is either considered as fresh water or saline water bearing zone. The confirmation of groundwater quality was obtained from the 64" normal log resistivity values as well as chemical analysis of water samples. The various correlated sections were then used in visualizing the number, disposition, and extension of aquifer groups in the study area as a whole. The electro-log of each well has been interpreted using S.P and resistivity geophysical logs. The granular zones have been interpreted in terms of saline and fresh aquifers. The hydrogeological framework in terms of lithological disposition and salinity is depicted in the form of fence diagram (Fig. 3). The regional picture of subsurface geology which emerges from the study is that, there exist five distinct units. Three distinct groups of permeable granular zones (aquifer groups) separated by two different impermeable horizons were identified. A perusal of Fig. 3 shows that the area north of the tract joining PotashpurBhagawanpur-Panskura ( PBP), the aquifer zones are all fresh throughout at all levels. However, a look into the lithological log, the aquifer group-I, in the southern part of this PBP tract consists mainly of clayey sand. Few thin sand within this group exists (as inferred through geophysical log) which is saline. As such there is no groundwater development in this zone. However, there exists perched aquifer in this part. The Aquifer-II south of PBP tract bears saline water. The Aquifer-II is underlained by regionally extensive grey clay. Beneath the grey clay horizon, Aquifer-III is delineated. Within this Aquifer group-III just below grey clay, in the area south of Potashpur-Bhagawanpur and in between Mayna and Tamluk, exists a saline water bearing sand. Care has to be taken while designing the well in this part of the aquifer to avoid any intermixing or saline water upconing. However the sand beneath this layer is fresh all along the basin. The interpreted lithology (based on geophysical log) along with water quality is shown in Table-3.

\subsection{Aquifer Geometry and Depth Structure Maps of Aquifer Groups}

Aquifer disposition and its geometry is the foundation upon which well design depends. An optimal drainage pattern and suitable well placement can be better designed with prior knowledge of aquifer geometry in terms of depth, thickness and spatial extension. The establishment of aquifer geometry will help to minimize the risk related to availability of resources, deliverability, impact on the environment and conflict with the stakeholders. In turn efficient design of water wells will further reduce the operational issues, drilling and operating expenses. Efforts have been made to establish and define aquifer geometry by integrating the sub-surface hydrogeological and geophysical datasets generated. 
The success of well design depends on the prior knowledge of top and bottom of the aquifer systems. A broad structural and lithological framework has been erected using the geophysical logs to define major lithological units and lateral correlativity of key marker horizons. Diagnostic clay horizons were picked in these wells and correlated regionally. The tops and bottoms of the aquifer groups and the intervening clay markers delineated have been used to generate depth structure (top and bottom) maps of all three aquifer groups delineated. These maps can be used for more optimal development strategy and efficient well designing for low costs and higher deliverability.

\subsubsection{Depth Structure Map of Aquifer-I}

The top and bottom of Aquifer-I generated is shown in Fig. 4a and Fig. 4b respectively. The top of Aquifer-I ranges between 1 to $53 \mathrm{~m}$ above mean sea level (AMSL). The bottom of Aquifer-I ranges between 32m AMSL to $65 \mathrm{~m}$ below mean sea level (BMSL). The lithological description explains that the southern part of fresh saline interface (FSI) marked as dotted line, is clayey in nature and though very thin sand is present within the clayey formation is mostly saline as inferred through geophysical logging. Groundwater in this part of the aquifer system is mostly available in perched condition as explained in Fig. 7a. Hence, in general the southern part of dashed line of Aquifer-l is not suitable for groundwater except few patches of perched water bearing sand. The isopach map of each aquifer groups are generated to aid in deciding the thickness of the zones to be tapped as per requirement. The isopach maps of Aquifer-I (Fig. 4c) show that the thickness varies from $4 \mathrm{~m}$ in the extreme north to $\sim 75 \mathrm{~m}$ in the southern part of the basin. However when overlapped with the fresh water-saline water interface, it infers that the thickness of freshwater ranges between $20 \mathrm{~m}$ to $40 \mathrm{~m}$. Though the thickness increases southerly but the formation is more clayey.

\subsubsection{Depth Structure Map of Aquifer-II}

The Aquifer-l is underlain by Aquifer-ll separated by a clay layer. However this marker clay is very thin and sandy in and around Medinipur and Kharagpur area and as such hydro geologically groundwater of Aquifer-ll is available in semi confined in north western part and becomes confined condition in the rest part of the basin. Fig. $5 \mathrm{a}$ and Fig. 5b respectively is the top and bottom depth structure maps of Aquifer-II. The top of Aquifer-II ranges between $12 \mathrm{~m}$ AMSL to $90 \mathrm{~m}$ BMSL. The bottom of Aquifer-II ranges between $6 \mathrm{~m}$ BMSL to $153 \mathrm{~m}$ BMSL. The isopach map of Aquifer-II (Fig. 5c) shows that the thickness of the aquifer ranges between $\sim 7 \mathrm{~m}$ in the north to $\sim 86 \mathrm{~m}$ in the south. The thickness of the aquifer in the freshwater zone ranges between $7 \mathrm{~m}$ to $30 \mathrm{~m}$ and that of saline water aquifer zone ranges between $30 \mathrm{~m}$ to $86 \mathrm{~m}$.

\subsubsection{Depth Structure Map of Aquifer-III}

The top and bottom of the third aquifer is shown as Fig. $6 \mathrm{a}$ and Fig. $6 \mathrm{~b}$ respectively. The top of Aquifer-III ranges between $13 \mathrm{~m}$ BMSL to $175 \mathrm{~m}$ BMSL. The bottom of Aquifer-III ranges between $143 \mathrm{~m}$ BMSL to $363 \mathrm{~m}$ BMSL.

\subsection{Iso-Conductivity Map and Aquifer Wise Salinity Zonation}

The quality of groundwater in the area has been depicted with the help of iso-conductance maps using EC of the monitoring wells in the area. The EC of the groundwater depends upon the concentration of dissolved salts. The objective of the study of variation of EC of the area is to assess the suitability of groundwater for various purposes. In order to assess the chemical quality of groundwater of aquifers of the area, the analyzed groundwater samples for EC of groundwater samples collected during May, 2019 from monitoring system of CGWB (CGWB,2019) and other exploratory wells have been considered to show distribution patterns of salinity (EC) in different ranges of suitability for drinking purposes ( BIS, 2012).

The iso-conductivity map has been prepared using EC of water samples tapping the shallow zone of Aquifer-I delineated. It is seen that, groundwater development of shallow zone is only in the northern part of the basin. Very few groundwater structures exists in the southern part ( Sinharay 2014, CGWB 2013). The locations of the monitoring wells in the unconfined Aquifer-l used for preparation of the map to demarcate the salinity zones is shown in the Fig. 1. A perusal of iso-conductivity map of Aquifer-I (Fig. 7a) shows that the electrical conductivity of groundwater in the unconfined part (Aquifer-I) is in general below $750 \mu \mathrm{S} / \mathrm{cm}$, i,e fresh. There are isolated patches within this aquifer where the $\mathrm{EC}$ is less than $250 \mu \mathrm{S} / \mathrm{cm}$ and can be inferred as mostly being recharged though rainfall. As explained in the earlier section, the shallower zones in the southern part of the basin being clayey in nature and groundwater is available is available in perched localized only. The EC of the perched aquifer is in general fresh. There are localized fresh water bearing sand near Panskura, Tamluk and Mahisadal in and around Kasai River in the southeastern part of the basin. There are pockets of saline groundwater ranging between $750-2250 \mu \mathrm{S} / \mathrm{cm}$. In and around Haldia, this shallow aquifer group bears more saline groundwater ranging between (2250-3000 $\mu \mathrm{S} / \mathrm{cm})$. Based on geophysical log interpretation and EC values of water samples, fresh water-saline water interface (FSI) has been demarcated by dashed line as shown in Fig. 7a. The same interface boundary has been overlaid over depth structure maps of the three aquifer groups which will aid to the well design.

The EC values of groundwater tapping the depth zones of Aquifer-II, through hand pumps or shallow tube wells in the basin are used to obtain the iso-conductivity map ( Fig. 7b). In general the electrical conductivity ranges between 250-750 $\mu \mathrm{S} / \mathrm{cm}$ in the northern part marked as FSI in Fig. 7b. Few zones of low EC $(<250 \mu \mathrm{S} / \mathrm{cm})$ is also recorded in and around Ghorabandhchati area. Few zones (EC between $750-2250 \mu \mathrm{S} / \mathrm{cm}$ ) 
in northern and eastern part of Kasai River are noticed inferring saline aquifer within freshwater aquifer. The anomaly in salinity value could be due to the reason that the well has tapped saline water bearing sand and has not been isolated properly from freshwater bearing sand, in other words it is a result of improper well design. South of this tract is entirely saline in various ranges of $750-2250 \mu S / \mathrm{cm}, 2250-3000$ $\mu \mathrm{S} / \mathrm{cm}$ and more than $3000 \mu \mathrm{S} / \mathrm{cm}$ in and around Haldia area in the extreme south eastern part of the basin.

The EC of water samples collected from well tapping the Aquifer-III is used for iso-conductivity mapping. The EC values considered are mostly of exploratory wells of CGWB and few monitoring wells were used. In general EC of groundwater is fresh $(<750 \mu S / \mathrm{cm})$. Few areas are having very low $(<250 \mu \mathrm{S} / \mathrm{cm})$ in and around Ghorabandhchati and Daspur area. In Haldia area this zone bears fresh water $(\mathrm{EC}<750 \mu \mathrm{S} / \mathrm{cm})$. Overall the groundwater of Aquifer-III can be utilized for fresh water abstraction.

\section{Well Design Proposed}

Proper design of water well is essential in order to obtain optimum quantity of groundwater economically from a given aquifer system. The choice of water wells mainly depends on the economic condition of users, depth to groundwater availability quantity and quality of water required. Major steps involved in the design of wells are: selection of suitable size of the well and casing; length and location of the screen, diameter of the screen ( Raghunath, 2007), slot size and shape, and percentage of opening (Todd, 1980); selection of casing and screen material, grain size analysis and design of gravel pack (Roscoe Moss, 1990). Properly designed water wells intends to ensure proper performance of the wells, reduced pumping and maintenance costs, and long service life of the well (Michael et al. ,2008). The various hydrogeological parameters such as yield of wells, drawdown and static water levels of existing wells in the nearby were considered as design parameters.

The cased portion of the well is designed first and then the intake portions of casings are sealed in place with grout which protects against the contamination by pollutants from the surface and acts as a seal for the casing. Poor grouting may create problems later as pump impellers and other mechanical parts are scoured by small particles moving into the well around the casing shoe. Poor grouting also may create voids when eventual corrosion of the casing wall allows unconsolidated sediments to enter the wall. The casing shoe should be as far as possible placed against the impermeable formation. As a model exercise wells have been designed at four locations two each on either side of Kasai River. The designs have been made separately for aquifer tapping shallow confined (Aquifer-II) and deeper confined (Aquifer-III). The depth of the wells has been decided on the basis of granular zones demarcated.

\subsection{Design of well Casing and screen}

The most important consideration in designing the well screen is to ensure that the drawdown within the well is minimized. The following principles have been taken into consideration to arrive at the Screen specifications and recommendations for flow though the screen and into the well the entrance velocity, Ve, is the velocity with which the groundwater enters the well through the well screen:

$$
\mathrm{V}_{\mathrm{e}}=\frac{\text { Pumping Rate }}{\text { Screen length } \mathrm{x} \pi \mathrm{x} \text { Screen Diameter } \mathrm{x} \text { Open area ratio } \mathrm{x} \text { Clogging factor }}
$$

It is normally accepted that the optimum entrance velocity $V_{e}$ should be less than $0.03 \mathrm{~m} / \mathrm{sec}(0.1 \mathrm{ft} / \mathrm{sec})$ in order to minimize head losses across the screen (Driscoll, F G, 1986). It is assumed that the water enters the screen uniformly along the full length of the screen. It is considered that $50 \%$ of the slots will be blocked (Driscoll, 1986) and hence the clogging factor and open area ratio is assumed to be 0.1 and 0.5 respectively.Table- 4 shows the minimum length of screen of various diameters that would be required for various pimping rates as practiced for shallow and deep tube wells in the area, considering maximum entrance velocity of $0.03 \mathrm{~m} / \mathrm{s}$.

The size and shape of the openings (slots) in the screen depend on the gradation, and the size and shape of the aquifer material so as to avoid entering of fine particles into the screen openings and to ensure that all the fine particles around the screen are washed out to improve the permeability of the aquifer material. The degree of sorting and size of grains of sediment are of considerable importance in groundwater studies for design of water wells. These are determined by mechanical analysis, which consists of separation of grains of various size or groups by passing through a set of standard sieves.

\subsubsection{Grain Size Study Using Sieve analysis of available Drill Cutting Samples}

Evaluation of grain size distribution of unconsolidated deposits is useful to evaluate parameters like effective size $\left(\mathrm{d}_{10}\right)$ and median size $\left(\mathrm{d}_{50}\right)$ of aquifer. The uniformity co-efficient determines the degree of sorting which in turn helps in calculating the screen slot and gravel size. The sieve analyses data of drill cutting samples for available 4 numbers of water wells against various sand zones are plotted which is used for 
well designing purposes. The grain size distribution curve (using sieve size of $4,1,0.5,0.25,0.125,0.088$ and $0.062 \mathrm{~mm}$ ) of drill cutting samples of demarcated zones of sand for Gopalpur, Lakhya, Kharagpur and Khejuri are shown in Fig. 8. The calculated parameters are shown in Table-5.

\subsubsection{Gravel Pack and Screen Slot Size}

The uniformity co-efficient $\left(U_{c}\right)$ of all the zones is calculated and found to be less than 3 , hence an artificial gravel pack is recommended ( Raghunath, 2007). The design procedure for selecting the gravel material is to determine the point $d_{30}$ of the gravel pack which is equal to 4 to 6 times the $d_{30}$ of the aquifer material obtained from the sieve analysis of the aquifer material samples and then drawing a smooth curve through this point (corresponding to $d_{30}$ of the gravel pack) representing a material with a uniformity coefficient of 2.5 or less (Fig. 9). This is the gradation of the gravel pack to be used (Raghunath, 2007). The slot size of the well screen is selected as $d_{10}$ of the gravel-pack material to avoid segregation of fine particles near the screen openings. The width of screen slots ranges from $1.2 \mathrm{~mm}$ for both the shallow and deeper aquifers. The gravel size ranges between 2-3mm.

\subsection{Generic Well Design}

The design of the water wells for the study area is done based on the result obtained from the study. The shallow unconfined aquifer (AquiferI) is to be used for construction of open dug wells or hand pumps (as practised in the area). The top and bottom of the structures can be decided on the basis of depth structure map of the area. The intermediate aquifer (Aquifer-II) and deeper aquifer (Aquifer-III) is to be designed for tube wells. The top and bottom of the screen can be decided based on the depth structure map delineated. However, the length and diameter of the screen can be decided on the basis of volume of water required (Table- 4). The generic well design has been made (Fig. 10) for four locations, two each on either side of Kasai and Suvarnarekha River. For sustainable development of groundwater in the area, saline groundwater can also be used for industrial purposes. As such, wells are designed by tapping saline water zones. Fig. 10a shows well design of Daspur tapping shallow and deeper aquifers. The well tapping deeper fresh water aquifer is designed in such a way to avoid any intermixing and as such packer is suggested at the top of the screen and proper cementation. Similar precautions have been suggested to isolate the different zones.

\section{Conclusion}

As a result of increasing population, industrialization and increasing water demand in agricultural sectors, groundwater table is lowering in most parts of Kasai River basin. It is a serious threat as regards to groundwater quality and quantity due to saline water up-coning and seawater intrusion. The hydro geophysical study was carried out in lower reaches of Kasai River using geophysical well logging data comprising of SP, resistivity, gamma and lithological logs to identify the granular zones and demarcation of aquifer groups along with saline and fresh water zones. The hydrogeological framework in terms of salinity variation laterally and vertically is presented in the form of fence diagram. The study showed that there are three aquifer systems present in the area.

The aquifer units in the region of investigation occur at different depths. The fence diagram prepared through correlation of logs shows that the saline water - freshwater interface is more towards in land for the shallow aquifer compared to the deeper ones. It is observed that the granular zone of shallow unconfined aquifer in the northern part of the basin is fresh. In general the EC of Aquifer-I ranges between 250$750 \mu \mathrm{S} / \mathrm{cm}$. However, in the southern part of area is clayey in nature and in general saline as inferred through geophysical logs. Few localized and isolated fresh water zones are present within the clayey formation. The aquifer geometry of Aquifer-II is also determined through correlation of logs and saline water/ freshwater interface is determined. The saline water/ freshwater interface is up to $39 \mathrm{Km}$ towards inland up to a depth range of 79-160m BGL. The EC of the aquifer ranges between 750-3000 $\mu \mathrm{S} / \mathrm{cm}$ in the southern part. The groundwater bearing sand of Aquifer-III is fresh all through, except in the southern part near the outfall of Suvarnarekha and Kasai River with Bay of Bengal.

The establishment of the sub-surface geometry through hydro geophysical studies is the foundation upon which a well design depends. Based on the sub-surface studies, aquifer top, bottom and thickness were used to design a well. Sieve analysis has been carried out to decide the gravel pack and screen slot size design. The uniformity co-efficient of the grain size distribution is less than 3 and hence artificial gravel pack is recommended for all the granular zones. The gravel pack of 2-3mm size is recommended for a successful well in the area. The screen slot size of $1.2 \mathrm{~mm}$ is also suggested. Proper cementation with packer is also suggested to isolate the different zones from intermixing and up coning.

Thus it can be concluded that this mapping exercise which consists of delineation of aquifer geometry along with salinity distribution will help the planner and various groundwater users in various groundwater development projects to design the well properly based on the interpreted top and thickness of the individual aquifers along with its salinity distribution. Another general and important aspect concerns the planning of proper and scientific water well drilling. One can perform rational well design with correct location of casing, screen and packer to avoid up coning as well as correct borehole location, make preliminary estimate to the depth to be reached and ultimately save time and cost 
for sustainable development. This study is meant to develop robust multilayer aquifer model and design water well which is an important step in the overall process that leads to understanding of aquifer disposition and salinity variation.

\section{Declarations}

Ethics Approval All authors certify that they have no affiliations with or involvement with or involvement in any organization or entity with any financial interest in the subject matter or materials discussed in this manuscript.

Consent to participate Informed consent was obtained from all individual participants included in the study.

Consent for publication All authors contributed to the study conception and design, material preparation, data collection were performed by authors.

Funding No funding, grants or other support was received.

Competing Interests The authors have no conflicts of interest to declare that are relevant to the content of this article.

Availability of data and materials Data are available from the corresponding author upon request.

\section{References}

1. Abdalla O, Ali M, Higgi A, Hinai S (2010) Rate of seawater intrusion estimated by geophysical methods in and arid area. Hydrogeol J 18:1437-1445. https://doi.org/10.1007/s10040-010-0606-0

2. Adeoti L, Alile OM, Uchegbulam O (2010) Geophysical investigation of saline water intrusion into fresh water aquifer: A case study of Onire, Lagos state. Sci Res Essays 5(3):248-259. https://ir.unilag.edu.ng/handle/123456789/5083

3. Akinlalu AA, Afolabi DO (2018) Borehole depth determination to freshwater and well design using geophysical logs in coastal regions of Lagos, southwestern Nigeria. Appl Water Sci 8:152. https://doi.org/10.1007/s13201-018-0798-3

4. Archie GE (1942) The electrical resistivity log as an aid in determining some reservoir characteristics. Petroleum Transactions of the AIME 146:54-62. https://doi.org/10.2118/942054-G

5. Barwani A, Helmi T (2006) Seawater intrusion in a coastal aquifer: A case study for the area between Seeb and Suwaiq in the Sultanate of Oman. Agricultural and Marine Sciences 11:55-69. https://doi.org/10.24200/10.24200/jams.vol26iss1pp1-12

6. Biswal S, Jha MK, Sharma SP (2018) Hydrogeologic and hydraulic characterization of aquifer and nonaquifer layers in a lateritic terrain (West Bengal, India). Hydrogeol J 26:1947-1973. https://doi.org/10.1007/s10040-018-1722-5

7. Bureau of Indian standards (2012) Indian standard drinking water specification (Second revision) IS 10500. http://cgwb.gov.in/Documents/WQ-standards.pdf

8. Central Ground Water Board (2010) Ground water quality in shallow aquifers of India. Technicalreport, Ministry of water resources, Government of India, Faridabad.http://cgwb.gov.in/WQ/gw_quality_in_shallow_aquifers.pdf

9. Central Ground Water Board (2013) Groundwaterinformationbooklet,PurbaMedinipurdistrict,WestBengal,India. TechnicalReport, Ministry of water resources, Government of India, New Delhi. http://cgwb.gov.in/District_Profile/WestBangal/Purba\%20Medinipur.pdf

10. Central Ground Water Board (2013) Groundwaterinformationbooklet,PaschimMedinipurdistrict,WestBengal,India; TechnicalReport, Ministry of water resources, Government of India, New Delhi. http://cgwb.gov.in/District_Profile/WestBangal/Paschim\%20Medinipur.pdf

11. Central Ground Water Board (2014) ReportonstatusofgroundwaterqualityincoastalaquifersofIndia; TechnicalReport, Ministry of water resources, Government of India, Faridabad. http://cgwb.gov.in/WQ/Costal\%20Report.pdf

12. Central Ground Water Board (2019) Groundwater year book; TechnicalReport, Ministry of water resources, Government of India, Kolkata. http://cgwb.gov.in/Regions/ER/Reports/GWYB\%202018-2019\%20WB\%20\&\%20AN.pdf

13. Chaturvedi PC, Chandra PC (2003) Identification of aquifers and their characteristics from geophysical logs. Bhujal-Jal News I 8:6. http://cgwb.gov.in/Documents/Bhujalnews-25-01-02.pdf Case studies

14. Custodio E, Paris (1987) https://unesdoc.unesco.org/ark:/48223/pf0000074510

15. Das S (2014) Impact on water quality in Piyali River, Sundarbans, India due to saline water intrusion. Indian Journal of Environmental Protection 34:1010-1019. https://www.researchgate.net/publication/270339144 )

16. Dhar S (2011) Impact of climate change on the salinity situation of the Piyali river, Sundarbans, India. Indian Journal of Environmental Protection 3:495-503. 10.4236/JWARP.2011.37059. DOI

Page 10/24 
17. Doll HG (1948) The SP Log: Theoretical analysis and principles of interpretation. American Institute of Mining, Metallurgical, and Petroleum Engineers Technical Publication. 2463 40. https://www.worldcat.org/title/s-p-log-theoretical-analysis-and-principles-of interpretation/oclc/ 16502103

18. Driscoll FG (1986) Groundwater and wells. Johnson Division, St. Paul, Minn. 1089 pp

19. Fligg K, Rodrigues E (1981) Case histories in the application of geophysical oil well logging in groundwater investigations. Water resources branch, Ontario ministry of environment, water resources paper, 12

20. Goswami AB (1968) A study of salt encroachment in the coastal aquifers at Digha, Medinipur district, West Bengal; Ind. Hydrological Sciences Journal 13:77-87. DOI: 10.1080/02626666809493609

21. Keys WA (1988) Boreholegeophysicsappliedtogroundwaterhydrology; U.S. Geological Survey. https://doi.org/10.3133/ofr87539

22. Kumar A, Sinha R (2010) Well field design for abstraction of high volume saline groundwater from Thumbli aquifer, Barmer basin, Rajasthan, India; Paper Presented in XXXVIII IAH Congress, Krakow, Poland. 1105-1113 http://home.agh.edu.pl/ iah2010/extab/extabstract/186-iah2010_kumar.pdf

23. Machiwal D, Jha MK (2016) Exploring hydrogeology and groundwater dynamics in a lateritic terrain of West Bengal, India, under limited data conditions. Environ Earth Science 75:831. https://doi.org/10.1007/s12665-016-5669-3

24. Maity PK, Das S, Das R (2017) Assessment of groundwater quality and saline water intrusion in the coastal aquifers of Purba Medinipur district, West Bengal, India. Indian Journal of Environmental protection 37:31-39. https://www.researchgate.net/publication/313240863

25. Mandal M, Dandapath P, Shashi B (2013) Digha Sankarpur littoral tract - A geographical case study. International Journal of Humanities and social science invention; 4:46-54. http://www.ijhssi.org/papers/v2(4)/version-2/I244654.pdf

26. Michael AM, Khepar SD, Sondhi SK (2008) Water Well and Pump Engineering. Second Edition, Tata McGraw Hill Education Pvt. Ltd., New Delhi

27. Oladopo MI, Hori OB, Adeoye-Oladidapo OO (2014) Geophysical study of saline water intrusion in Lagos municipality. Afr J Environ Sci Rechnology 8(1):16-30

28. Raghunath HM (2007) Ground Water. Third Edition, New Age International Publishers, New Delhi

29. Reese R, Wacker M (2007) Hydrostratigraphic frame work and selection and correlation of geophysical log markers in surfacial aquifer system, Palm beach county Florida; Report of US department of Interior, USGS. https://pubs.usgs.gov/sim/2971/pdf/sim2971_pg1.pdf

30. Roscoe Moss Co (1990) Handbook of ground water development. Wiley, New York

31. Singh SC (2013) Groundwater in the coastal zones of Asia-Pacific; Coastal Research Library. 67-87. https://doi/10.1007/978-94-0075648-9_5

32. Sinha R, Israil M, Singhal. DC (2009) A hydrogeophysical model for relationships between geoelectric and geohydraulic parameters of anisotropic aquifers. J Hydrol 17:495-503. https://doi.org/10.1007/s10040-008-0424-9

33. Sinha R, Kumar A (2019) Characterisation of a deep saline aquifer using oil exploration data in an arid region of Rajasthan, India. ; In: In: Ray S (ed) Ground Water Development - Issues and Sustainable Solutions. Springer, Singapore. https://doi.org/10.1007/978-981-13-

1771-2_4.

34. Sinharay SP (2014)

GroundwaterscenarioofthecoastalareaofwestbengalwithspecialreferencetotheSustainableuseofgroundwater;Technicalreport,ICZMproject. http://www.iczmpwb.org/main/pdf/physical_progress/Draft\%20report\%20on\%20Ground\%20Water\%20Scenario.pdf

35. Todd DK (1980) Groundwater hydrology. John Wiley \& sons, New York

36. United Nations Education Science and Cultural Organisation (1982) Water problems in coastal areas

37. United Nations Education Science and Cultural Organisation (1982), Water problems in coastal areas

\section{Tables}

Table-1 Hydrogeological parameters of the study area 
Pre-monsoon
depth to water level (m bgl)
Post-monsoon depth to water level (m bgl)

\section{Tentative aquifer zones ( $\mathrm{m}$ bgl)}

Yield of wells

$\left(\mathrm{m}^{3} / \mathrm{hr}\right)$ and DD (m)

Shallow Deep Shallow Deep aquifer aquifer aquifer aquifer

Bhagawanpur $\quad$ Major aquifer bearing is Quaternary
within $75 \mathrm{~m}$ and Tertiary. Major

16.5

4.8

7.5

$20-50 ; 68-71 ; 89-$
$92 ; 140-146 ; 167-$
$170 ; 218-221$

\section{STW :} aquifer is found within $150-250 \mathrm{~m}$.

$170 ; 218-221$

Yield 15-

$30 \mathrm{~m}^{3} / \mathrm{hr}$;

DD 7-10m

DTW:

Yield 60-

$150 \mathrm{~m}^{3} / \mathrm{hr}$

; DD 4-8m

$\begin{array}{ll}\text { Daspur } & \text { Recent /Quaternary alluvium } \\ \text { underlain by tertiary sediments. } & \text { Tertiary aquifer exist below145 to } \\ & 165 \mathrm{~m} \text { bgl. }\end{array}$

14.5

15.76

5.5

3.4

45-

174

STW

Yield 15-

$25 \mathrm{~m}^{3} / \mathrm{hr}$;

DD 6-12m

DTW

Yield 75-

$150 \mathrm{~m}^{3} / \mathrm{hr}$;

DD 3-10m

\begin{tabular}{|c|c|c|c|c|c|c|c|}
\hline \multirow[t]{2}{*}{ Debra } & \multirow[t]{2}{*}{$\begin{array}{l}\text { Quaternary alluvium underlain by } \\
\text { Tertiary sediments. Tertiary aquifer } \\
\text { exists below } 95 \text { to } 120 \mathrm{~m} \text { bgl. }\end{array}$} & \multirow[t]{2}{*}{17.95} & \multirow[t]{2}{*}{18.34} & \multirow[t]{2}{*}{7.26} & \multirow[t]{2}{*}{3.26} & \multirow[t]{2}{*}{$\begin{array}{l}3-10 ; 15-27 ; 97- \\
110 ; 125-129 ; 133- \\
136 ; 150-160 ; 182- \\
196\end{array}$} & $\begin{array}{l}\text { STW } \\
\text { Yield 20- } \\
40 \mathrm{~m}^{3} / \mathrm{hr} \\
\text { DD 7-10m }\end{array}$ \\
\hline & & & & & & & $\begin{array}{l}\text { DTW } \\
\text { Yield 75- } \\
150 \mathrm{~m}^{3} / \mathrm{hr} \\
\text {; DD 4-8m }\end{array}$ \\
\hline \multirow[t]{2}{*}{ Haldia } & \multirow[t]{2}{*}{$\begin{array}{l}\text { Major aquifer bearing is Quaternary } \\
\text { and Tertiary. Major aquifer is found } \\
\text { between } 120-250 \mathrm{~m} \text {, below } 250 \mathrm{~m} \text { is } \\
\text { clayey sand }\end{array}$} & \multirow[t]{2}{*}{15.76} & \multirow[t]{2}{*}{9.56} & \multirow[t]{2}{*}{14.6} & \multirow[t]{2}{*}{4.17} & \multirow[t]{2}{*}{$\begin{array}{l}55-64 ; 102-108 ; 116- \\
121 ; 130-138 ; 155- \\
160 ; 164-170 ; 177- \\
183 ; 200-225\end{array}$} & $\begin{array}{l}\text { STW } \\
\text { Yield } 80- \\
100 \mathrm{~m}^{3} / \mathrm{hr} \\
\text { DD } 20 \mathrm{~m}\end{array}$ \\
\hline & & & & & & & $\begin{array}{l}\text { DTW } \\
\text { Yield } \\
140 \mathrm{~m}^{3} / \mathrm{hr} ; \\
\text { DD } 18 \mathrm{~m}\end{array}$ \\
\hline \multirow[t]{3}{*}{ Kharagpur-I } & \multirow[t]{3}{*}{$\begin{array}{l}\text { Partly laterite covered. Quaternary } \\
\text { alluvium underlain by tertiary } \\
\text { sediments. Tertiary aquifer exists } \\
\text { below } 75 \text { to } 100 \mathrm{~m} \text { bgl. }\end{array}$} & $\begin{array}{l}\text { DW: } \\
5.16\end{array}$ & \multirow[t]{3}{*}{9.2} & \multirow[t]{3}{*}{$\begin{array}{l}\text { DW: } \\
3.26 \\
7.1\end{array}$} & \multirow[t]{3}{*}{3.14} & \multirow[t]{3}{*}{$\begin{array}{l}2-10 ; 20-25 ; 54-58 ; 65- \\
70 ; 80-101 ; 106- \\
125 ; 135-140 ; 145- \\
155\end{array}$} & $\begin{array}{l}\text { DW Yield } \\
5- \\
8 \mathrm{~m}^{3} / \mathrm{hr} ; \\
\text { DD 6-8m }\end{array}$ \\
\hline & & & & & & & $\begin{array}{l}\text { STW } \\
\text { Yield 15- } \\
25 \mathrm{~m}^{3} / \mathrm{hr} \\
\text { DD } 10 \mathrm{~m}\end{array}$ \\
\hline & & & & & & & $\begin{array}{l}\text { DTW } \\
\text { Yield } 50- \\
100 \mathrm{~m}^{3} / \mathrm{hr} \\
\text { DD } 5 \mathrm{~m}\end{array}$ \\
\hline \multirow[t]{3}{*}{ Mahisadal } & \multirow[t]{3}{*}{$\begin{array}{l}\text { Quaternary alluvium underlain by } \\
\text { Tertiary sediments; aquifer exist up } \\
\text { to within } 125-300 \text { m depth }\end{array}$} & \multirow[t]{3}{*}{6.52} & \multirow[t]{3}{*}{7.85} & \multirow[t]{3}{*}{4.61} & \multirow[t]{3}{*}{7.25} & \multirow[t]{3}{*}{$\begin{array}{l}56-62 ' 137-143 ; 150- \\
156 ; 183-189 ; 213- \\
222 ; 240-252 ; 257- \\
263 ; 330-346\end{array}$} & $\begin{array}{l}\text { STW } \\
\text { Yield } 80- \\
100 \mathrm{~m}^{3} / \mathrm{hr} \\
\text { DD } 20 \mathrm{~m}\end{array}$ \\
\hline & & & & & & & $\begin{array}{l}\text { DTW } \\
\text { Yield }\end{array}$ \\
\hline & & & & & & & $\begin{array}{l}170 \mathrm{~m}^{3} / \mathrm{hr} ; \\
\text { DD } 5 \mathrm{~m}\end{array}$ \\
\hline Moyna & $\begin{array}{l}\text { Major aquifer bearing is Quaternary } \\
\text { within } 75 \mathrm{~m} \text { and in Tertiary, major } \\
\text { aquifer is found within } 90-250 \mathrm{~m} \text {. }\end{array}$ & 13.2 & 14.5 & 4.01 & 4.12 & $\begin{array}{l}68-71 ; 89-92 ; 140- \\
146 ; 167-170 ; 218- \\
221\end{array}$ & $\begin{array}{l}\text { STW } \\
\text { Yield 20- } \\
35 \mathrm{~m}^{3} / \mathrm{hr} \\
\text { DD 5-10m }\end{array}$ \\
\hline
\end{tabular}

Page $12 / 24$ 


\begin{tabular}{|c|c|c|c|c|c|c|c|}
\hline Medinipur & $\begin{array}{l}\text { Quaternary alluvium underlain by } \\
\text { Tertiary sediments. Tertiary aquifer } \\
\text { exists below } 70 \text { to } 90 \mathrm{~m} \text { bgl. }\end{array}$ & $\begin{array}{l}\text { DW: } \\
5.85 \\
12.3\end{array}$ & 13.7 & $\begin{array}{l}\text { DW: } \\
4.95\end{array}$ & 10.2 & $\begin{array}{l}3-12 ; 18-27 ; 35-45 ; 50- \\
80 ; 97-110 ; 125- \\
129 ; 133-136 ; 150- \\
160 ; 182-196 ; 205- \\
208 ; 231-240\end{array}$ & $\begin{array}{l}\text { DW Yield } \\
5- \\
8 \mathrm{~m} 3 / \mathrm{hr} ; \\
\text { DD 6-8m } \\
\text { STW } \\
\text { Yield 20- } \\
40 \mathrm{~m}^{3} / \mathrm{hr} ; \\
\text { DD 5-11m } \\
\text { DTW } \\
\text { Yield 75- } \\
150 \mathrm{~m}^{3} / \mathrm{hr} ; \\
\text { DD 8-10m }\end{array}$ \\
\hline Panskura-I & $\begin{array}{l}\text { Major aquifer bearing is Quaternary } \\
\text { within } 70 \mathrm{~m} \text { and in Tertiary, major } \\
\text { aquifer is found within } 90-230 \mathrm{~m} \text {. }\end{array}$ & $\begin{array}{l}\text { DW: } 8.7 \\
11.8\end{array}$ & $\begin{array}{l}4.68 \\
10\end{array}$ & $\begin{array}{l}\text { DW: } 6.3 \\
8.9\end{array}$ & $\begin{array}{l}14.52 \\
7.6\end{array}$ & $\begin{array}{l}44-48 ; 62-64 ; 86- \\
90 ; 137-149 ; 161- \\
173 ; 216-228\end{array}$ & $\begin{array}{l}\text { STW } \\
\text { Yield 20- } \\
35 \mathrm{~m}^{3} / \mathrm{hr} ; \\
\text { DD 5-10m } \\
\text { DTW } \\
\text { Yield } \\
200 \mathrm{~m}^{3} / \mathrm{hr} \text {; } \\
\text { DD } 4-6 \mathrm{~m}\end{array}$ \\
\hline Pingla/Jalchak & $\begin{array}{l}\text { Quaternary alluvium underlain by } \\
\text { Tertiary sediment. Tertiary aquifer } \\
\text { exists below } 130 \text { to } 150 \mathrm{~m} \text { bgl. }\end{array}$ & $\begin{array}{l}18.12 \\
12.6\end{array}$ & 11 & 10.36 & 8.5 & $\begin{array}{l}47-67 ; 110-120 ; 130- \\
147 ; 160-170 ; 177- \\
187\end{array}$ & $\begin{array}{l}\text { STW } \\
\text { Yield 20- } \\
40 \mathrm{~m}^{3} / \mathrm{hr} ; \\
\text { DD 5-10m } \\
\text { DTW } \\
\text { Yield 75- } \\
150 \mathrm{~m}^{3} / \mathrm{hr} ; \\
\text { DD } 4-8 \mathrm{~m}\end{array}$ \\
\hline Sutahata & $\begin{array}{l}\text { Major aquifer bearing is Quaternary } \\
\text { and Tertiary. Major aquifer is found } \\
\text { between } 120-250 \mathrm{~m} \text { below } 250 \mathrm{~m} \text { is } \\
\text { clayey sand. }\end{array}$ & 12 & 10 & 10 & 8 & $\begin{array}{l}55-64 ; 102-108 ; 116- \\
121 ; 130-136 ; 155- \\
160 ; 164-170 ; 177- \\
183 ; 203-225\end{array}$ & $\begin{array}{l}\text { STW } \\
\text { Yield } 80- \\
100 \mathrm{~m}^{3} / \mathrm{hr} ; \\
\text { DD } 20 \mathrm{~m} \\
\text { DTW } \\
\text { Yield } \\
140 \mathrm{~m}^{3} / \mathrm{hr} \text {; } \\
\text { DD } 18 \mathrm{~m}\end{array}$ \\
\hline Tamluk & $\begin{array}{l}\text { Quaternary Alluvium underlain by } \\
\text { Tertiary sediments; aquifer exists up } \\
\text { to } 180 \mathrm{~m} \text {. }\end{array}$ & 13 & 11 & 12 & 10 & $\begin{array}{l}55-64 ; 102-108 ; 116- \\
121 ; 130-138 ; 155- \\
160 ; 164-170 ; 177- \\
183 ; 200-225\end{array}$ & $\begin{array}{l}\text { STW } \\
\text { Yield 20- } \\
35 \mathrm{~m}^{3} / \mathrm{hr} ; \\
\text { DD 5-10m } \\
\text { DTW } \\
\text { Yield } \\
200 \mathrm{~m}^{3} / \mathrm{hr} ; \\
\text { DD } 4-6 \mathrm{~m}\end{array}$ \\
\hline Khejuri-I & $\begin{array}{l}\text { Major aquifer is found in Mio- } \\
\text { Pliocene sediments; aquifer exists } \\
\text { between } 234-291 \mathrm{~m} \text { bgl. }\end{array}$ & 14 & 10 & 10 & 9 & $\begin{array}{l}50-60 ; 226-228 ; 236- \\
254 ; 265-280\end{array}$ & $\begin{array}{l}\text { STW } \\
\text { Yield 40- } \\
80 \mathrm{~m}^{3} / \mathrm{hr} ; \\
\text { DD 8-20m } \\
\text { DTW } \\
\text { Yield } \\
220 \mathrm{~m}^{3} / \mathrm{hr} \text {; } \\
\text { DD } 4-6 \mathrm{~m}\end{array}$ \\
\hline
\end{tabular}




\begin{tabular}{|c|c|c|c|c|c|c|c|}
\hline \multirow{2}{*}{$\begin{array}{l}\text { Sl. } \\
\text { No. }\end{array}$} & \multirow[t]{2}{*}{ Location } & \multicolumn{3}{|c|}{ Marker Clay Horizon ( MC) } & \multicolumn{3}{|c|}{ Marker Grey Clay Horizon (GC) } \\
\hline & & $\begin{array}{l}\text { Depth Range ( } \\
\mathrm{m})\end{array}$ & $\begin{array}{l}\text { Gamma } \\
\text { (CPS) }\end{array}$ & $\begin{array}{l}\text { Resistivity } \\
(\Omega \mathrm{m})\end{array}$ & $\begin{array}{l}\text { Depth Range ( } \\
\text { m) }\end{array}$ & $\begin{array}{l}\text { Gamma } \\
\text { (CPS) }\end{array}$ & $\begin{array}{l}\text { Resistivity ( } \\
\Omega \mathrm{m})\end{array}$ \\
\hline 1 & Debra & $12-48$ & 29 & 15 & $93-110$ & 130 & 9 \\
\hline 2 & Daspur & $45-70$ & 39 & 17 & $157-187$ & 130 & 12 \\
\hline 3 & Jalchak & $30-35$ & 34 & 14 & $64-68$ & 160 & 29 \\
\hline 4 & Narghat & $31-49$ & 27 & 13 & $73-75$ & 110 & 10 \\
\hline 5 & Gopalpur & $21-76$ & 56 & 12 & $125-137$ & 135 & 20 \\
\hline 6 & Bhagawanpur & $42-62$ & 58 & 13 & $89-93$ & 150 & 12 \\
\hline 7 & Lakshya & $62-96$ & 85 & 14 & $147-158$ & 130 & 12 \\
\hline 8 & Gogras Kesabpur & $13-65$ & 76 & 16 & $115-140$ & 128 & 10 \\
\hline 9 & Kapasaria & $59-85$ & 82 & 17 & $121-133$ & 140 & 3 \\
\hline 10 & $\begin{array}{l}\text { Maheshpur High } \\
\text { School }\end{array}$ & $72-80$ & 76 & 14 & $113-120$ & 165 & 6 \\
\hline 11 & Haldia ANC & $50-70$ & 84 & 12 & $150-176$ & 160 & 8 \\
\hline 12 & Haldia IOC & $55-75$ & 82 & 11 & $160-175$ & 165 & 8 \\
\hline 13 & Haldia Cluster-9 & $52-69$ & 85 & 14 & $152-175$ & 160 & 7 \\
\hline 14 & Sutahata & $55-80$ & 82 & 15 & $136-148$ & 162 & 8 \\
\hline 15 & Khejuri & $71-79$ & 83 & 12 & $111-127$ & 130 & 8 \\
\hline 16 & Panskura & $17-51$ & 82 & 14 & $89-94$ & 145 & 12 \\
\hline 17 & Tamluk & $23-73$ & 86 & 17 & $125-131$ & 150 & 14 \\
\hline 18 & Geonkhali & $62-96$ & 82 & 16 & $147-158$ & 148 & 10 \\
\hline 19 & Durgachak & $53-73$ & 81 & 15 & $156-177$ & 160 & 9 \\
\hline 20 & Haldia IOC-BH8 & $54-73$ & 84 & 14 & $165-176$ & 163 & 8 \\
\hline 21 & Kasaria High school & $72-78$ & 81 & 13 & $111-125$ & 134 & 8 \\
\hline 22 & Haldia IOC-BH12 & $53-74$ & 81 & 14 & $165-174$ & 168 & 9 \\
\hline
\end{tabular}

Table 3 Granular zones interpreted through Geophysical Logs 


\begin{tabular}{|c|c|c|c|c|c|}
\hline $\begin{array}{l}\text { Sl. } \\
\text { No. }\end{array}$ & Borehole Site & $\begin{array}{l}\text { Depth } \\
\text { Drilled/ } \\
\text { logged } \\
\text { ( } \mathrm{m} \mathrm{bgl)}\end{array}$ & Anomaly Measured & Granular Zones ( $\mathrm{m}$ bgl) & $\begin{array}{l}\text { Quality of } \\
\text { Water } \\
\text { Inferred }\end{array}$ \\
\hline 1 & Debra & $220 / 200$ & Moderate SP and high resistivity & $\begin{array}{l}0-5 ; 35-50 ; 60-78 ; 95-105 ; 118-125 ; 138- \\
148 ; 163-179\end{array}$ & $\begin{array}{l}\text { Fresh all } \\
\text { through }\end{array}$ \\
\hline 2 & Daspur & $360 / 350$ & Moderate SP and high resistivity & $\begin{array}{l}18-30 ; 32-35 ; 68-100 ; 130-157 ; 162- \\
210 ; 252-300 ; 325-351\end{array}$ & $\begin{array}{l}\text { Fresh all } \\
\text { through }\end{array}$ \\
\hline 3 & Jalchak & $154 / 150$ & Moderate SP and high resistivity & $\begin{array}{l}22-30 ; 42-48 ; 59-72 ; 90-100 ; 131- \\
140 ; 162-171 ; 180-210 ; 133-150\end{array}$ & $\begin{array}{l}\text { Fresh all } \\
\text { through }\end{array}$ \\
\hline \multirow[t]{2}{*}{4} & \multirow[t]{2}{*}{ Narghat } & \multirow[t]{2}{*}{$252 / 250$} & $\begin{array}{l}\text { A low resistive zone recording negative S.P } \\
\text { granular zone having effective porosity }\end{array}$ & $12-26 ; 50-56 ; 66-76 ; 84-100$ & Saline \\
\hline & & & Moderate SP and high resistivity & $\begin{array}{l}126-154 ; 164-174 ; 182-198 ; 207- \\
136 ; 242-249\end{array}$ & Fresh \\
\hline \multirow[t]{2}{*}{5} & \multirow[t]{2}{*}{ Gopalpur } & \multirow[t]{2}{*}{$\begin{array}{l}304.8 / \\
303.6\end{array}$} & $\begin{array}{l}\text { A low to moderately resistive zone recording } \\
\text { negative S.P; granular zone having effective } \\
\text { porosity }\end{array}$ & $\begin{array}{l}\text { 54.8-60.3;84.1-92.7;96.9-101.2;107.3- } \\
\text { 117;138-150.0; }\end{array}$ & Saline \\
\hline & & & Moderate SP and high resistivity & 164..1-180.0;190-203.0;235-285 & Fresh \\
\hline 6 & Bhagawanpur & $230 / 228$ & Moderate SP and high resistivity & $\begin{array}{l}12-25 ; 62-71 ; 80-82 ; 103-128 ; 141- \\
170 ; 190-202-212-218\end{array}$ & $\begin{array}{l}\text { Fresh all } \\
\text { through }\end{array}$ \\
\hline \multirow[t]{2}{*}{7} & \multirow[t]{2}{*}{ Lakshya } & \multirow[t]{2}{*}{$\begin{array}{l}253.84 / \\
252.32\end{array}$} & $\begin{array}{l}\text { A low moderately resistive zone recording } \\
\text { negative S.P; granular zone having effective } \\
\text { porosity }\end{array}$ & 3.1-28.8;44-81;116-140;157-178 & Saline \\
\hline & & & Moderate SP and high resistivity & $210-252$ & Fresh \\
\hline \multirow[t]{2}{*}{8} & \multirow[t]{2}{*}{$\begin{array}{l}\text { Gogras } \\
\text { Kesavpur }\end{array}$} & \multirow[t]{2}{*}{$260 / 254$} & $\begin{array}{l}\text { moderate resistivity; mixed zone; semi } \\
\text { pervious }\end{array}$ & $\begin{array}{l}0-10 ; 49-56 ; 60-69 ; 71-78 ; 90-100 ; 104- \\
116\end{array}$ & Saline \\
\hline & & & Moderate SP and high resistivity & $\begin{array}{l}155-165 ; 182-193 ; 198-212 ; 219- \\
227 ; 235-245\end{array}$ & Fresh \\
\hline \multirow[t]{2}{*}{9} & \multirow[t]{2}{*}{ Kapasaria } & \multirow[t]{2}{*}{$375 / 372$} & $\begin{array}{l}\text { A low moderately resistive zone recording } \\
\text { negative S.P; granular zone having effective } \\
\text { porosity }\end{array}$ & $\begin{array}{l}21-32 ; 39.5-50.6 ; 62-171 ; 78-86 ; 104- \\
118 ; 134-165\end{array}$ & Saline \\
\hline & & & Moderate SP and high resistivity & $\begin{array}{l}168-205 ; 215-228 ; 236-252 ; 272- \\
309 ; 330-350\end{array}$ & Fresh \\
\hline \multirow[t]{2}{*}{10} & \multirow[t]{2}{*}{$\begin{array}{l}\text { Maheshpur } \\
\text { High School }\end{array}$} & \multirow[t]{2}{*}{$300 / 295$} & $\begin{array}{l}\text { A low moderately resistive zone recording } \\
\text { negative S.P; granular zone having effective } \\
\text { porosity }\end{array}$ & $57-61 ; 66-73$ & Saline \\
\hline & & & Moderate SP and high resistivity & $\begin{array}{l}85-93 ; 102-109 ; 120-127 ; 144-164 ; 172- \\
179 ; 191-212 ; 217-249 ; 255-277\end{array}$ & Fresh \\
\hline \multirow[t]{2}{*}{11} & \multirow[t]{2}{*}{ Haldia ANC } & \multirow{2}{*}{$\begin{array}{l}300.57- \\
296.0\end{array}$} & A low resistive zone recording negative S.P ; & $68-90 ; 122-129.5 ; 134-144$ & Saline \\
\hline & & & Moderate SP and high resistivity & $178-183 ; 209-220 ; 229-254 ; 262-278$ & Fresh \\
\hline \multirow[t]{2}{*}{12} & \multirow[t]{2}{*}{ Haldia IOC } & \multirow[t]{2}{*}{$\begin{array}{l}284 / \\
274\end{array}$} & $\begin{array}{l}\text { A low moderately resistive zone recording } \\
\text { negative S.P; granular zone having effective } \\
\text { porosity }\end{array}$ & $38-71 ; 71-90$ & Saline \\
\hline & & & Moderate SP and high resistivity & $142-154 ; 163-171 ; 195-209 ; 223-227$ & Fresh \\
\hline \multirow[t]{2}{*}{13} & \multirow{2}{*}{$\begin{array}{l}\text { Haldia } \\
\text { Cluster-9 }\end{array}$} & \multirow{2}{*}{$\begin{array}{l}250 / \\
246\end{array}$} & A low resistive zone recording negative S.P ; & $100-130$ & saline \\
\hline & & & $\begin{array}{l}\text { A moderately to high resistive zone } \\
\text { recording positive S.P }\end{array}$ & $144-161.0 ; 169.5-173.0 ; 212.0-223.0$ & Fresh \\
\hline \multirow[t]{2}{*}{14} & \multirow[t]{2}{*}{ Sutahata } & \multirow[t]{2}{*}{$250 / 245$} & $\begin{array}{l}\text { A low moderately resistive zone recording } \\
\text { negative S.P; granular zone having effective } \\
\text { porosity }\end{array}$ & $45-50 ; 80-136 ; 158.6-164.7$ & Saline \\
\hline & & & Moderate SP and high resistivity & $170.0-189.0$ & Fresh \\
\hline 15 & Khejuri & $400 / 399$ & $\begin{array}{l}\text { A low moderately resistive zone recording } \\
\text { negative S.P; granular zone having effective }\end{array}$ & $20-38 ; 49-60 ; 68-79 ; 89-110 ; 135-153$ & Saline \\
\hline
\end{tabular}


porosity

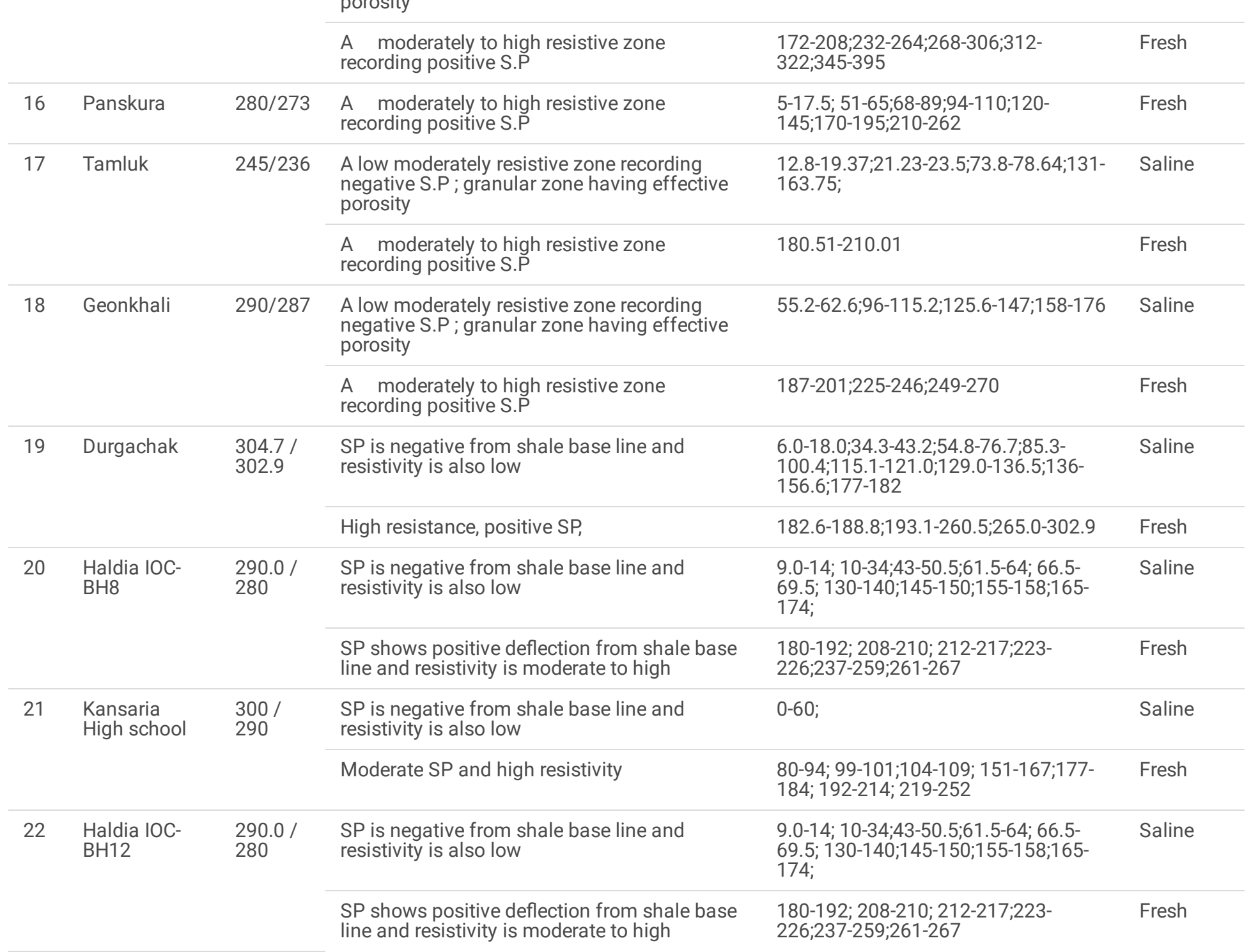

Table-4 Minimum Length of Screen needed to satisfy entrance velocity requirement 


\begin{tabular}{|c|c|c|c|c|c|c|c|}
\hline \multirow[t]{3}{*}{ Location } & \multirow[t]{3}{*}{ Aquifer Type } & \multirow[t]{3}{*}{ Yield (m3/hr) } & & \multicolumn{4}{|c|}{ Nominal Screen Diameter (m) } \\
\hline & & & & 0.15 & 0.2 & 0.25 & 0.3 \\
\hline & & & & \multicolumn{4}{|c|}{ Minimum length of screen required $(\mathrm{m})$} \\
\hline \multirow[t]{6}{*}{ Daspur } & \multirow[t]{3}{*}{ Shallow Aquifer } & Minimum Yield & 15 & 5.90 & 4.42 & 3.54 & 2.95 \\
\hline & & Maximum Yield & 25 & 9.83 & 7.37 & 5.90 & 4.91 \\
\hline & & Average Yield & 20 & 7.86 & 5.90 & 4.72 & 3.93 \\
\hline & \multirow[t]{3}{*}{ Deeper Aquifer } & Minimum Yield & 75 & 29.49 & 22.12 & 17.69 & 14.74 \\
\hline & & Maximum Yield & 150 & 58.98 & 44.23 & 35.39 & 29.49 \\
\hline & & Average Yield & 100 & 39.32 & 29.49 & 23.59 & 19.66 \\
\hline \multirow[t]{6}{*}{ Lakhya(Mahisadal) } & \multirow[t]{3}{*}{ Shallow Aquifer } & Minimum Yield & 80 & 31.45 & 23.59 & 18.87 & 15.73 \\
\hline & & Maximum Yield & 100 & 39.32 & 29.49 & 23.59 & 19.66 \\
\hline & & Average Yield & 90 & 29.49 & 22.12 & 17.69 & 14.74 \\
\hline & \multirow[t]{3}{*}{ Deeper Aquifer } & Minimum Yield & 130 & 51.11 & 38.33 & 30.67 & 25.56 \\
\hline & & Maximum Yield & 170 & 66.84 & 50.13 & 40.10 & 33.42 \\
\hline & & Average Yield & 150 & 58.98 & 44.23 & 35.39 & 29.49 \\
\hline \multirow[t]{6}{*}{ Bhagwanpur } & \multirow[t]{3}{*}{ Shallow Aquifer } & Minimum Yield & 15 & 5.90 & 4.42 & 3.54 & 2.95 \\
\hline & & Maximum Yield & 30 & 11.80 & 8.85 & 7.08 & 5.90 \\
\hline & & Average Yield & 22 & 8.65 & 6.49 & 5.19 & 4.32 \\
\hline & \multirow[t]{3}{*}{ Deeper Aquifer } & Minimum Yield & 60 & 23.59 & 17.69 & 14.15 & 11.80 \\
\hline & & Maximum Yield & 150 & 58.98 & 44.23 & 35.39 & 29.49 \\
\hline & & Average Yield & 100 & 39.32 & 29.49 & 23.59 & 19.66 \\
\hline \multirow[t]{6}{*}{ Khejuri } & \multirow[t]{3}{*}{ Shallow Aquifer } & Minimum Yield & 40 & 15.73 & 11.80 & 9.44 & 7.86 \\
\hline & & Maximum Yield & 80 & 31.45 & 23.59 & 18.87 & 15.73 \\
\hline & & Average Yield & 60 & 23.59 & 17.69 & 14.15 & 11.80 \\
\hline & \multirow[t]{3}{*}{ Deeper Aquifer } & Minimum Yield & 140 & 55.04 & 41.28 & 33.03 & 27.52 \\
\hline & & Maximum Yield & 220 & 86.50 & 64.87 & 51.90 & 43.25 \\
\hline & & Average Yield & 180 & 70.77 & 53.08 & 42.46 & 35.39 \\
\hline
\end{tabular}

\section{Table - 5 Results of Sieve Analysis}




\begin{tabular}{|c|c|c|c|c|c|c|}
\hline Location & $\begin{array}{l}\text { Depth range } \\
\text { (meter) }\end{array}$ & $\begin{array}{l}\text { Effective size }\left(d_{10}\right) \\
(\mathrm{mm})\end{array}$ & $\begin{array}{l}\text { Size }\left(d_{30}\right) \\
(m m)\end{array}$ & $\begin{array}{l}\text { Median Size }\left(d_{50}\right) \\
(\mathrm{mm})\end{array}$ & $\begin{array}{l}\operatorname{Size}\left(d_{60}\right) \\
(m m)\end{array}$ & $U c=d_{60} / d_{10}$ \\
\hline \multirow[t]{5}{*}{ Gopalpur } & $55.0-60.9$ & 0.21 & 0.44 & 0.65 & 0.57 & 2.71 \\
\hline & $85.3-93.5$ & 0.17 & 0.25 & 0.35 & 0.4 & 2.35 \\
\hline & $97.5-100.6$ & 0.15 & 0.41 & 0.37 & 0.42 & 2.8 \\
\hline & $107.2-122.5$ & 0.35 & 0.36 & 1.5 & 1.02 & 2.91 \\
\hline & $140.7-153.0$ & 0.36 & 0.38 & 0.7 & 1.05 & 2.92 \\
\hline \multirow[t]{5}{*}{ Lakhya } & $68.9-82.3$ & 0.17 & 0.4 & 0.39 & 0.46 & 2.71 \\
\hline & $95.0-107.0$ & 0.32 & 0.35 & 0.74 & 0.92 & 2.88 \\
\hline & $141.5-147.4$ & 0.25 & 0.38 & 0.55 & 0.74 & 2.96 \\
\hline & 159.1-162.1 & 0.17 & 0.29 & 0.39 & 0.46 & 2.71 \\
\hline & 208.8-211.8 & 0.16 & 0.24 & 0.305 & 0.35 & 2.19 \\
\hline \multirow[t]{5}{*}{ Kharagpur } & $20-25$ & 0.28 & 0.41 & 0.73 & 0.82 & 2.93 \\
\hline & $50-70$ & 0.25 & 0.32 & 0.59 & 0.74 & 2.96 \\
\hline & $80-100$ & 0.31 & 0.38 & 0.65 & 0.91 & 2.94 \\
\hline & $120-130$ & 0.33 & 0.36 & 0.79 & 0.95 & 2.88 \\
\hline & $140-155$ & 0.19 & 0.41 & 0.46 & 0.56 & 2.95 \\
\hline \multirow[t]{5}{*}{ Khejuri } & $15-25$ & 0.15 & 0.31 & 0.45 & 0.44 & 2.93 \\
\hline & $50-60$ & 0.19 & 0.34 & 0.45 & 0.561 & 2.95 \\
\hline & $226-228$ & 0.14 & 0.28 & 0.45 & 0.41 & 2.93 \\
\hline & $236-254$ & 0.21 & 0.29 & 0.5 & 0.59 & 2.81 \\
\hline & $265-280$ & 0.19 & 0.35 & 0.395 & 0.46 & 2.42 \\
\hline
\end{tabular}

Figures 


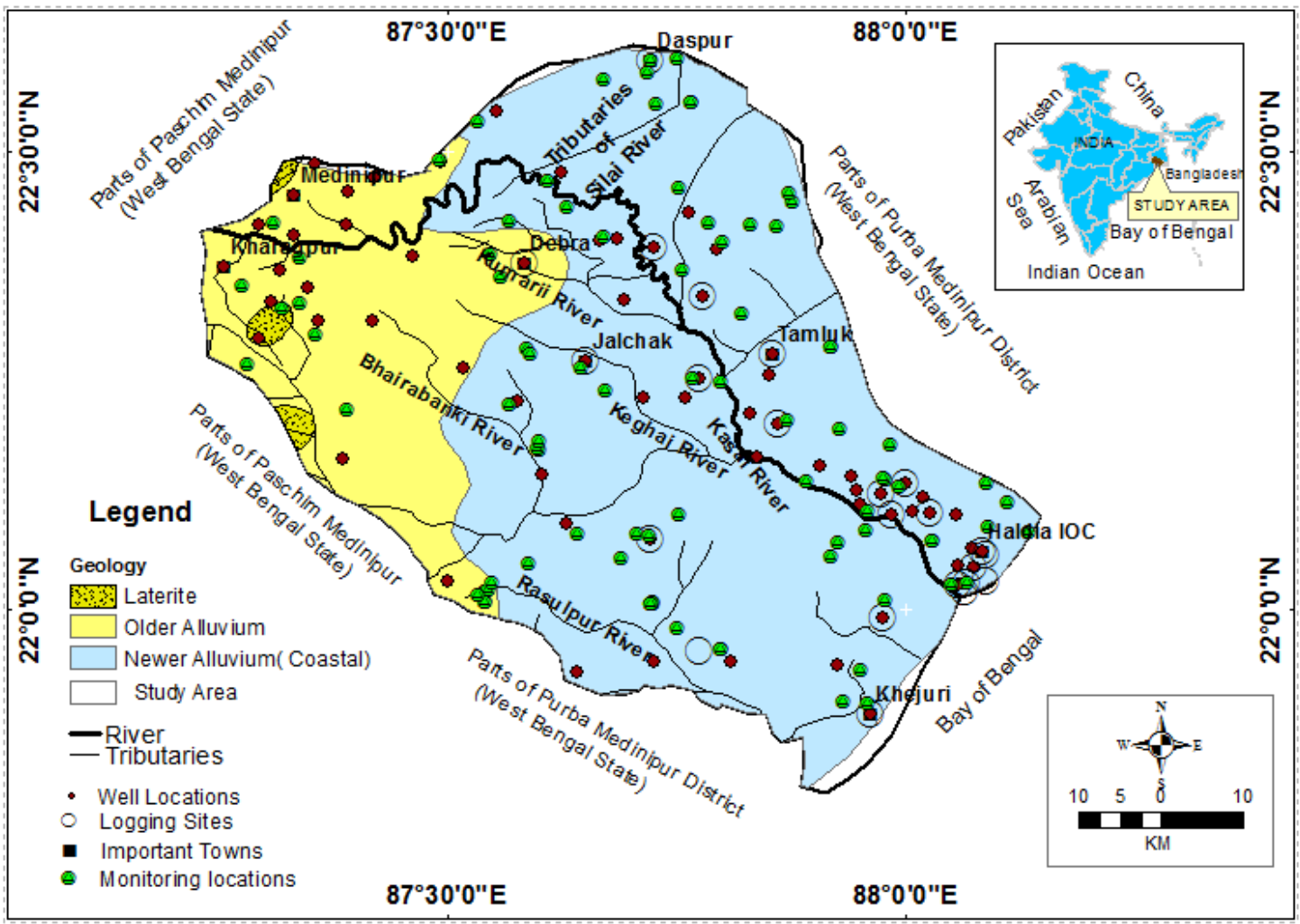

Figure 1

Geological map (after GSI, 1999) of the study area with locations of wells analyzed

Figure 2

Geo-electric section (a) Along Eastern bank of Kasai River (Daspur and Haldia section), 


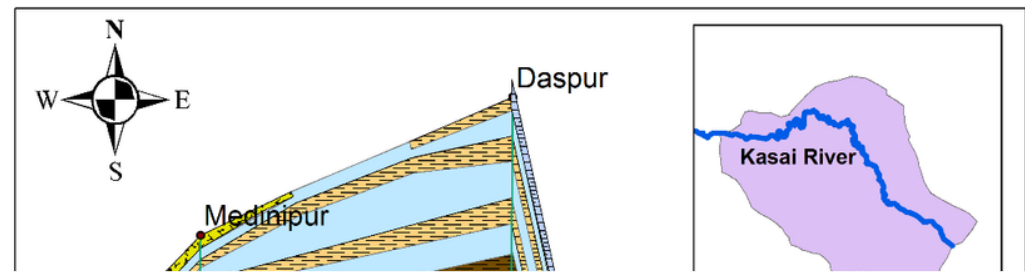

\section{Figure 3}

Fence diagram showing lithological disposition in the basin

\section{Figure 4}

Depth structure map of Aquifer-l; (a) Depth to top , (b) Depth to bottom, (c) Isopach Map

\section{Figure 5}

Depth structure map of Aquifer-II; (a) Depth to top , (b) Depth to bottom, (c) Isopach Map 


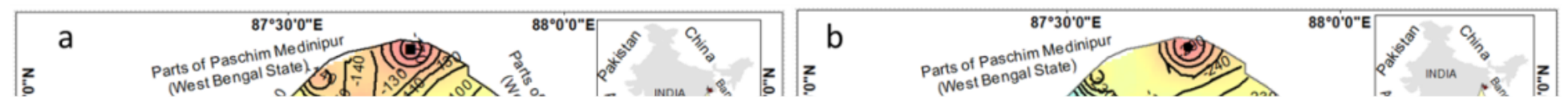

\section{Figure 6}

Depth structure map of Aquifer-III; (a) Depth to top, (b) Depth to bottom, (c) Isopach Map 


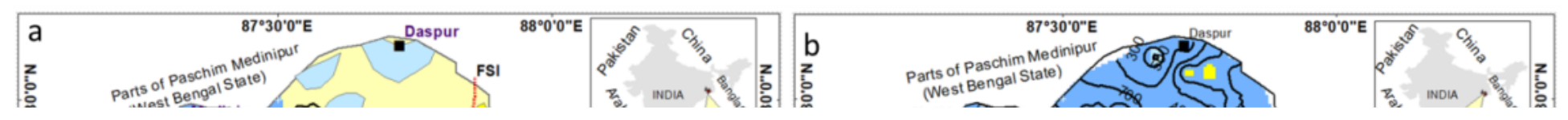

\section{Figure 7}

Iso-conductivity map; (a) Aquifer-I, (b) Aquifer-II, (c) Aquifer-III 

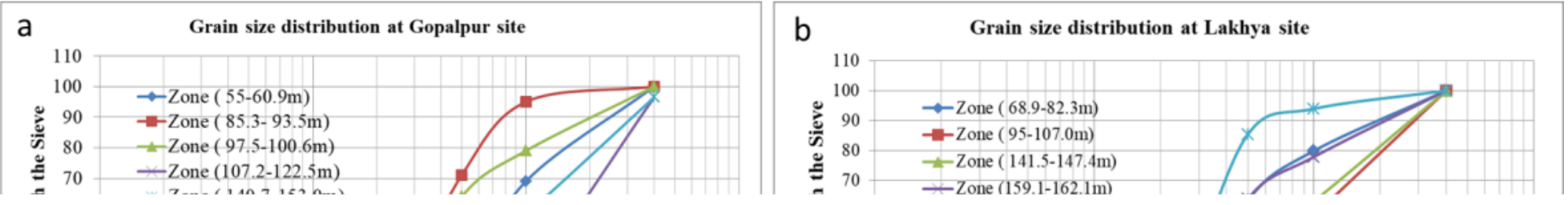

\section{Figure 8}

Grain size distribution; (a) Gopalpur site, (b) Lakhya Site, (c) Kharagpur Site, (d) Khejuri Site 


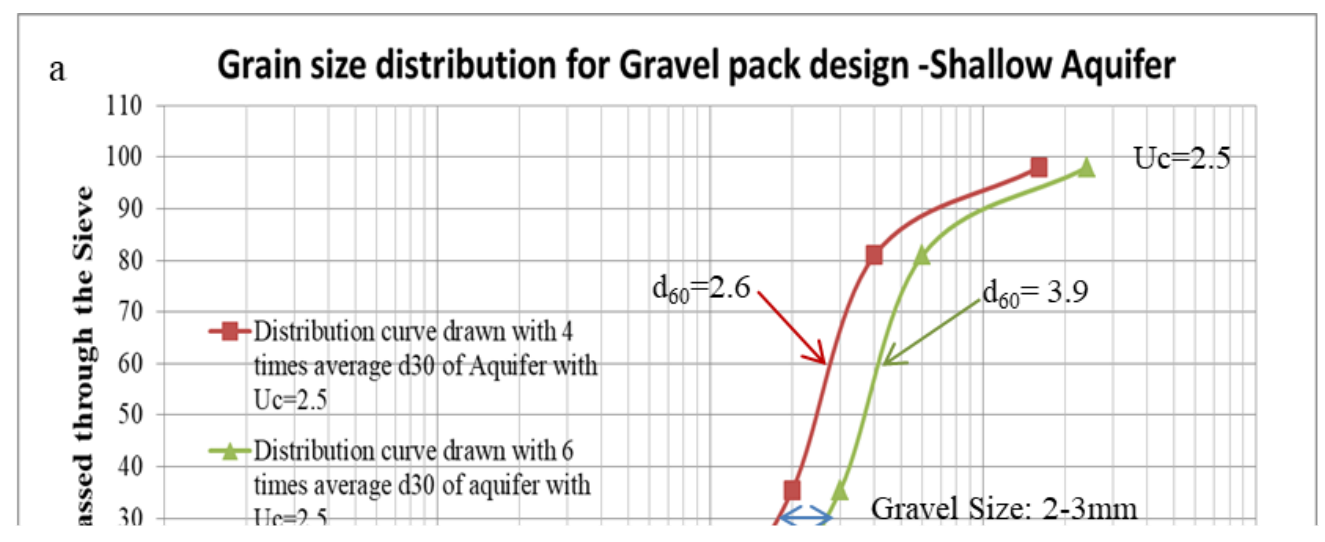

Figure 9

Grain Size distribution curve illustrating the design of gravel pack (a) Shallow Aquifer, (b) Shallow Aquifer

Figure 10

Generic Water Well Design (a) Daspur, (b) Lakhya, (c) Bhagwanpur, (d) Khejuri 